\title{
Assessing floods and droughts in the Mékrou River basin (West Africa): a combined household survey and climatic trends analysis approach
}

\author{
Vasileios Markantonis ${ }^{1}$, Fabio Farinosi ${ }^{1}$, Celine Dondeynaz ${ }^{1}$, Iban Ameztoy ${ }^{1}$, Marco Pastori ${ }^{1}$, Luca Marletta ${ }^{1}$, \\ Abdou $\mathrm{Ali}^{2}$, and Cesar Carmona Moreno ${ }^{1}$ \\ ${ }^{1}$ European Commission, Joint Research Centre, Ispra, Italy \\ ${ }^{2}$ AGRHYMET Regional Centre, Niamey, Niger
}

Correspondence: Vasileios Markantonis (vmarkantonis@gmail.com)

Received: 31 May 2017 - Discussion started: 20 June 2017

Revised: 7 March 2018 - Accepted: 8 March 2018 - Published: 2 May 2018

\begin{abstract}
The assessment of natural hazards such as floods and droughts is a complex issue that demands integrated approaches and high-quality data. Especially in African developing countries, where information is limited, the assessment of floods and droughts, though an overarching issue that influences economic and social development, is even more challenging. This paper presents an integrated approach to assessing crucial aspects of floods and droughts in the transboundary Mékrou River basin (a portion of the Niger River basin in West Africa), combining climatic trends analysis and the findings of a household survey. The multivariable trend analysis estimates, at the biophysical level, the climate variability and the occurrence of floods and droughts. These results are coupled with an analysis of household survey data that reveals the behaviour and opinions of local residents regarding the observed climate variability and occurrence of flood and drought events, household mitigation measures, and the impacts of floods and droughts. Based on survey data analysis, the paper provides a per-household cost estimation of floods and droughts that occurred over a 2-year period (2014-2015). Furthermore, two econometric models are set up to identify the factors that influence the costs of floods and droughts to impacted households.
\end{abstract}

\section{Introduction}

Extreme meteorological events such as droughts and floods represent an important limitation for the development of the poorest countries, cause loss of lives, damage to dwellings and vulnerable rural infrastructures, reduction of capital stock, and agricultural and industrial production losses. They also pose a general threat to food security and development, leading to shocks in labour productivity, energy security, and political instability (Dell et al., 2014; Hsiang, 2010). In developing countries, agriculture remains the main economic activity, and farming practices are mainly represented by rain-fed agriculture (Rosegrant et al., 2002). Agriculture, a sector extremely vulnerable to extreme events, is the main source of income and often the only means of self-sufficiency of the poorest portions of the rural population in the least developed countries, including sub-Saharan Africa (Gautam, 2006; Hellmuth et al., 2007). Floods and droughts, together with other natural disasters, were found to have a particularly damaging impact on the African continent, in particular with respect to fatalities, affected population, and economic damages (Cavallo, 2011). A recent study (Shiferaw et al., 2014), for instance, found that frequent drought conditions have limited the economic growth of many African countries and frustrated the benefits derived from development strategies implemented in the education and technological innovation sectors, confirming the findings of a previous study (Toya and Skidmore, 2007). Reduced precipitation was found to be responsible for about 15 to $40 \%$ of the gap between the per capita gross domestic product of African economies and that of the rest of the developing world (Barrios et al., 2010). The negative impact on economic growth of the stresses due to ever-increasing dry con- 
ditions and precipitation was also confirmed by Berlemann and Wenzzel (2015), who found drought-prone countries to be generally characterised by lower education levels, lower saving rates, and higher fertility levels. For these reasons, in the recent past, the disaster risk management community has extensively worked on the development of methodologies that aim to monitor the risk-prone areas and the overall vulnerability of the population threatened by the hydrometeorological hazards (UNISDR, 2017, 2013, 2011,2008, 2004). Progress has been made in the assessment of the occurrence of extreme events, their magnitude, and the expected climate change impacts (Alfieri et al., 2012; Hallegatte, 2012). Additional efforts were directed towards the improvement of both the assessment of risk and the estimation of the direct and indirect impacts, in particular those related to loss of human lives, economic activities, infrastructure, and natural and man-made capital (UNISDR, 2015). Technical advancement efforts also allowed for an improved assessment of current mitigation measures and policies (Bouwer et al., 2011; Bubeck and Kreibich, 2011; Green et al., 2011; Logar and van den Bergh, 2011; Markantonis et al., 2012). However, the benefits derived from the progress made in this discipline were mainly concentrated in the most developed and technically advanced countries, where information is more readily available and mitigation strategies are more likely to be effectively implemented (UNISDR, 2015). In the case of African countries, the assessment of the physical impacts of hazard events followed the general level of technical development. As in the most advanced countries, in fact, the occurrence of floods and droughts was assessed by applying remotesensing-based techniques, analysing precipitation and temperature records and their spatiotemporal distribution, as for instance in a case study in Kenya carried out by Ngigi et al. (2005).

Although several quantitative and qualitative approaches have been developed in assessing costs of natural hazards, information about losses caused by past extreme events is still too limited to facilitate a detailed cost estimation and impact assessment analysis for many African countries. As described in Markantonis et al. $(2012,2013)$, the methodologies used in the literature are various: hedonic pricing, travel cost, cost of illness approach, replacement cost, contingent valuation, choice modelling, and life satisfaction analysis (Welsch and Kühling, 2009; Luechinger and Raschky, 2009; Welsch, 2006). In this study, however, it was decided to estimate the cost of natural disasters in the case study area based on the direct testimony of the affected population. Several studies used household surveys to acquire qualitative and quantitative information from the local population in order to estimate the damages of past hydrometeorological events (as, for instance, in Fitchett et al., 2016; Ologunorisa and Adeyemo, 2005). Depending on the key economic sectors of the case study area, various examples of cost and impact assessment could be listed. Among the most representative were studies analysing the following sectors: health (Schmitt et al., 2016), agriculture and food security (Ngigi et al., 2005; Shiferaw et al., 2014; Shisanya and Mafongoya, 2016), and tourism (Fitchett et al., 2016). An analysis of the hazard components and the various impact assessments conducted in the recent past allowed for the evaluation of risk mitigation measures and adaptation strategies. For instance, Shisanya and Mafongoya (2016) analysed the effectiveness of shifts in agricultural practices; Brower et al. (2009) focused on the evaluation of the installation of risk mitigation infrastructures; Oyekale (2015) analysed the implementation of more advanced forecasting and early warning systems; Halsnæs and Trærup (2009) focused on the implementation of specific integrated policies and practices for floods and droughts. In some of these studies, cost-benefit and willingness-to-pay analyses were used to add quantitative evidence to the qualitative descriptions.

The objective of this paper is to assess the occurrence of flood and drought events, estimate damage costs at the household level, and describe the current mitigation behaviours adopted by the population of the Mékrou River basin, a small catchment area in West Africa. It combines a quantitative approach for detecting hydrometeorological hazard-prone areas (through the analysis of gridded climate datasets) with a qualitative and quantitative analysis of a household survey. This approach allows for the comparison of physical analyses of extreme events with human perceptions of the flood and drought phenomena in the Mékrou River basin. The household survey provides sufficient information to estimate the impacts of natural hazards in terms of economic cost and to present the most widely adopted mitigation behaviours.

Mékrou is a sub-basin of the Niger River, covering an area of $10635 \mathrm{~km}^{2}$, about $3 \%$ of the total Niger basin surface, across three countries Benin ( $80 \%$ of the basin territory), Burkina Faso (10\%), and Niger (10\%). Mean annual precipitation ranges from a maximum of about $1300 \mathrm{~mm}$ in the southern region and $500 \mathrm{~mm}$ in the north. The wet season occurs between June and September, with average cumulated rainfall of $700 \mathrm{~mm}$. Temperatures are also highly variable in space and time. The warmest and coldest months are April and September, respectively. Mean annual temperatures vary between 26 and $30^{\circ} \mathrm{C}$, reaching a maximum of $35-40^{\circ} \mathrm{C}$ and minimum of $15-19^{\circ} \mathrm{C}$. The Mékrou catchment is located in a temperate transitional area characterised by a wet season that peaks in August and a long dry season that spans the period December-April (Masih et al., 2014). During the wet season, the whole Niger River basin is subject to regular floods. Extensive research has been conducted on its complex hydrology, which is characterised by a large system of lakes and wetlands known as the Inland Delta (Bader et al., 2016; Tarpanelli et al., 2017), while less attention has been given to the Mékrou sub-basin. Flood and drought events are extremely frequent (Froidurot and Diedhou, 2017), and the impacts of climate change on their frequency and magnitude is unclear (Gautam, 2006). The Mékrou River basin is characterised by lack of or poor infrastructural development and 
very low socioeconomic conditions. Agriculture is the key economic sector, with the arable land used for food production, cattle farming, and the production of cotton. Therefore, climate variability is the main threat to the food and economic security of the area.

This paper is structured as follows: Sect. 2 presents the methodological framework regarding the development and application of the household survey (Sect. 2.1) and the analysis of the biophysical variables (Sect. 2.2). The findings of this integrated approach are given in Sect. 3. This section analytically presents the findings regarding precipitation patterns, temperature, and river discharge in the Mékrou River basin. Moreover, it includes the main findings of the household survey concerning the observed occurrence of floods, droughts and climate variability, household mitigation measures, the impacts of floods and droughts, and an econometric estimation of the costs of floods and droughts. Section 4 summarises the main findings of this approach, discusses its potential and limitations, and presents the main conclusions.

\section{Methodology}

\subsection{Household survey implementation and analysis}

A household survey to evaluate several water-related dynamics, including extreme natural hazards, was designed in 2015 and conducted in early 2016 (February to April). Specific villages and towns were selected to include a geographically representative sample of the river basin that belongs to the three countries (Benin, Burkina Faso, and Niger). The selection process was designed to keep a balance between urban and rural settlements. The number of households proportionally represents the total population of the respective villages or towns selected, and the number of households per country represents the country's population within the basin. Since there were no available lists of households that include their socioeconomic conditions we have selected them randomly based on their location in the village/town, keeping a distance of five households between those interviewed. Table 1 presents the detailed sample and population of the selected villages. The survey was carried out by experts of the Joint Research Centre of the European Commission in cooperation with local universities from Benin, Niger, and Burkina Faso. Interviews were conducted in person by a team of students supervised by a professor for each country. Before starting the survey, the students received training in which the questionnaire was thoroughly explained and discussed. Since the area is francophone, all the material used was written in French. The fact that the survey was conducted by students of local universities facilitated communication with the local population, overcoming possible language and cultural barriers. Prior to the conduction of the survey the survey country administrators visited each selected village and informed the local authorities. This process secured the ac- ceptance of the survey on the ground, resulting in a $100 \%$ response rate. The information included in the household survey aimed to retrieve opinions and observations based on personal judgement. A large section of the survey focused on identifying and assessing the impacts and costs of flood and drought events, climate variability, and household mitigation measures. Regarding the occurrence of floods and droughts in the study area, two time periods were selected: 10 years (2006-2015) and 2 years (2014-2015). The logic behind this selection was to identify the most recent events ( 2 years), for which the local households still had a fresh memory of the impacts suffered. The second time period (10 years) offers a longer assessment of climate variability and the occurrence of floods and droughts, which could potentially still be evaluated according to personal judgement. The whole questionnaire is included in Appendix A.

The survey process resulted in the collection of 660 randomly surveyed questionnaires retrieved from the areas of the three countries (Benin, Burkina Faso, and Niger) that are located in the Mékrou catchment (Fig. 1). Specifically, 332 questionnaires were collected in 16 villages from the municipalities (called "communes" in French) of Banikoara, Kouande, and Kerou in Benin; 148 questionnaires were collected in 6 villages from the communes of Diagaga and Tansarga in Burkina Faso; and 180 questionnaires were collected in 8 villages from the communes of Falmey and Tamou in Niger. The total number of surveyed households offers greater than $95 \%$ significance in the statistical findings (a minimum of 400 questionnaires are required for $95 \%$ significance rate). In Table 2 we present basic information on the socioeconomic characteristics of the surveyed population.

Following the data cleaning and validation of the survey, the information collected was statistically analysed, including all the parameters investigated in the questionnaire. The survey responses were evaluated using descriptive statistics that aggregate data both at river basin and at country level. The findings were analysed at the river basin scale, illustrating the differences between the three countries.

Apart from the statistical analysis, an econometric estimation was applied to identify the specific parameters that are highly correlated to the costs of droughts and floods that were incurred in the last 2 years of the study (2014 2015). Hence, besides the cost estimation based on the sample mean, two econometric models were set up to investigate the determinants of flood and drought costs following a cause-effect logic. Performing a thorough multivariate regression cost analysis of floods and droughts as stated in the survey and other covariates (such as socioeconomic characteristics of the population, impacts, and mitigation measures) led to the construction of models that could be used to explain the costs of extreme hydrometeorological events. Several types of regression models were tested, both linear and logarithmic. Linear multivariate regression models were finally chosen since they fit the selected variables with a higher statistical performance level. Moreover, in order to ensure the 
Table 1. Sample and population of the survey area.

\begin{tabular}{|c|c|c|c|c|c|c|}
\hline \multicolumn{7}{|c|}{ Population of the Mékrou area of interest } \\
\hline Benin & Burkina Faso & Niger & \multicolumn{4}{|l|}{ Total area } \\
\hline 294921 & 79632 & 173115 & \multicolumn{4}{|l|}{547668} \\
\hline \multicolumn{7}{|c|}{ Surveyed sample (households) } \\
\hline Benin & Burkina Faso & Niger & \multirow{2}{*}{\multicolumn{4}{|c|}{$\begin{array}{l}\text { Total area } \\
660\end{array}$}} \\
\hline 332 & 148 & 180 & & & & \\
\hline \multicolumn{7}{|c|}{ Sample (number of households) by selected communes } \\
\hline \multicolumn{3}{|l|}{ Benin } & \multicolumn{2}{|l|}{ Burkina Faso } & \multicolumn{2}{|l|}{ Niger } \\
\hline Banikorara & Kérou & Kouandé & Diapaga & Tansagra & Tamou & Birni Ngaoure \\
\hline 160 & 80 & 92 & 95 & 53 & 100 & 80 \\
\hline \multicolumn{7}{|c|}{ Population and sample (number of households) by selected village/town } \\
\hline \multicolumn{7}{|c|}{ Banikoara } \\
\hline & Sampéto & Gbéniki (Kérémou) & Wangouwirou & Banikoara (town) & Total & \\
\hline Population & 1522 & 786 & 3799 & 28402 & 32987 & \\
\hline Sample & 29 & 20 & 52 & 52 & 153 & \\
\hline \multicolumn{7}{|c|}{ Kouande } \\
\hline & Béket Bouramè & Mékrou-Gourou & Goufanrou & Kouandé (town) & Total & \\
\hline Population & 1876 & 2635 & 1835 & 20723 & 27069 & \\
\hline Sample & 20 & 27 & 20 & 25 & 92 & \\
\hline \multicolumn{7}{|c|}{ Kérou } \\
\hline & Koussou Ouinra & Yakrigourou & Bipotoké & Kérou (town) & Total & \\
\hline Population & 2842 & 2766 & 2871 & 34246 & 42725 & \\
\hline Sample & 16 & 19 & 16 & 36 & 87 & \\
\hline \multicolumn{7}{|c|}{ Diapaga } \\
\hline & Mangou & Tyaga & Diapaga (town) & Total & & \\
\hline Population & 1600 & 1136 & 16000 & 18736 & & \\
\hline Sample & 28 & 20 & 40 & 88 & & \\
\hline \multicolumn{7}{|c|}{ Tansagra } \\
\hline & Kotchari & Lada & Tansarga (town) & Total & & \\
\hline Population & 1024 & 720 & 14000 & 15744 & & \\
\hline Sample & 20 & 16 & 24 & 60 & & \\
\hline \multicolumn{7}{|c|}{ Birni Ngaoure } \\
\hline & Boumba & Fono Birgui & Kotaki & Flamey Djema (town) & Total & \\
\hline Population & 1414 & 560 & 2447 & 4467 & 8888 & \\
\hline Sample & 12 & 8 & 20 & 40 & 80 & \\
\hline \multicolumn{7}{|c|}{ Tamou } \\
\hline & Tankoune & Diney Bangou & Foulan Walagorou & Tamou (town) & Total & \\
\hline Population & 827 & 724 & 261 & 1827 & 3639 & \\
\hline Sample & 28 & 28 & 4 & 40 & 100 & \\
\hline
\end{tabular}


Table 2. Socioeconomic characteristics of the surveyed sample.

\begin{tabular}{|c|c|c|c|c|c|c|c|c|}
\hline \multicolumn{9}{|c|}{ Age (sample respondents) } \\
\hline \multirow{2}{*}{\multicolumn{2}{|c|}{ Benin }} & \multirow{2}{*}{\multicolumn{2}{|c|}{$\begin{array}{l}\text { Burkina } \\
\text { Faso }\end{array}$}} & \multirow[t]{2}{*}{ Niger } & & \multirow{2}{*}{\multicolumn{3}{|c|}{ Total }} \\
\hline & & & & & Area & & & \\
\hline Mean & SD & Mean & SD & Mean & $\mathrm{SD}$ & Mean & $\mathrm{SD}$ & \\
\hline 41.2 & 14.9 & 44.2 & 16.2 & 49.5 & 15.3 & 44.2 & 15.7 & \\
\hline \multicolumn{9}{|c|}{ Age distribution (total area population based on survey aggregation) } \\
\hline & Benin & Burkina Faso & Niger & Total area & & & & \\
\hline $0-5$ & $17.10 \%$ & $23.50 \%$ & $20.20 \%$ & $19.50 \%$ & & & & \\
\hline $5-18$ & $32.90 \%$ & $34.40 \%$ & $31.30 \%$ & $32.70 \%$ & & & & \\
\hline $18+$ & $49.90 \%$ & $42.10 \%$ & $48.60 \%$ & $47.90 \%$ & & & & \\
\hline \multicolumn{9}{|c|}{ Gender (sample respondents) } \\
\hline & \multicolumn{2}{|c|}{ Benin } & \multicolumn{2}{|c|}{ Burkina Faso } & Niger & & \multicolumn{2}{|c|}{ Total area } \\
\hline & Count & $\%$ & Count & $\%$ & Count & $\%$ & Count & $\%$ \\
\hline Male & 226 & $68.1 \%$ & 95 & $64.2 \%$ & 129 & $71.7 \%$ & 450 & $68.2 \%$ \\
\hline Female & 106 & $31.9 \%$ & 53 & $35.8 \%$ & 51 & $28.3 \%$ & 210 & $31.8 \%$ \\
\hline \multicolumn{9}{|c|}{ Education (sample respondents) } \\
\hline & $\begin{array}{l}\text { No } \\
\text { schooling }\end{array}$ & $\begin{array}{l}\text { No formal } \\
\text { school }\end{array}$ & $\begin{array}{l}\text { Primary } \\
\text { school }\end{array}$ & $\begin{array}{l}\text { Secondary } \\
\text { education }\end{array}$ & Professional & \multicolumn{3}{|l|}{ University } \\
\hline Count & 389 & 87 & 81 & 78 & 8 & \multicolumn{3}{|l|}{17} \\
\hline$\%$ & $58.90 \%$ & $13.20 \%$ & $12.30 \%$ & $11.80 \%$ & $1.20 \%$ & \multicolumn{3}{|l|}{$2.60 \%$} \\
\hline \multicolumn{9}{|c|}{ Profession (sample respondents) } \\
\hline & Unemployed & $\begin{array}{l}\text { Self- } \\
\text { employed }\end{array}$ & $\begin{array}{l}\text { Public } \\
\text { employee }\end{array}$ & $\begin{array}{l}\text { Farmer } \\
\text { farmer }\end{array}$ & Livestock & \multicolumn{3}{|l|}{ Other } \\
\hline$\%$ & $7.70 \%$ & $18.90 \%$ & $2.30 \%$ & $50.10 \%$ & $15.90 \%$ & \multicolumn{3}{|l|}{$5.10 \%$} \\
\hline \multicolumn{9}{|c|}{ Household income (FCFA per month) EUR 1 =FCFA 656 (sample respondents) } \\
\hline & $\begin{array}{l}0- \\
25000\end{array}$ & $\begin{array}{l}25001- \\
50000\end{array}$ & $\begin{array}{l}50001- \\
75000\end{array}$ & $\begin{array}{l}75001- \\
100000\end{array}$ & $\begin{array}{l}\text { More than } \\
100001\end{array}$ & \multicolumn{3}{|l|}{ Unknown } \\
\hline Count & 200 & 100 & 77 & 37 & 414 & \multirow{2}{*}{\multicolumn{3}{|c|}{$\begin{array}{l}121 \\
18.40 \%\end{array}$}} \\
\hline$\%$ & $30.50 \%$ & $15.20 \%$ & $11.70 \%$ & $5.60 \%$ & $18.60 \%$ & & & \\
\hline
\end{tabular}

coherence and readability of the models, only independent variables whose $p$ value was less than 0.05 were selected. One independent variable with a $p$ value greater than 0.05 was included due to its importance in the context of the analysis, but its value (0.068) is still below the least acceptable $p$ value $(0.1) . R$-square and $F$-test values were estimated, and correlation among the independent variables was tested in order to avoid bias in the model due to collinearity.

\subsection{Analysis of biophysical variables: precipitation, temperature, and river discharge}

Precipitation and temperature patterns and changes are the main drivers of local populations' perception of water availability, especially in an area where the main economic activity is based on rain-fed agricultural production. In order to ensure an efficient interpretation of household survey's results, quantitative estimates of trends in climate-related vari- ables are needed to understand the underlying direct (rainfall and discharge) and indirect (heat waves) factors that have an impact on the respondents answers. As analysis of rainfall events above and below the long-term average distribution in conjunction with inter- and intra-annual analyses are useful for depicting anomaly patterns and trends. They help better understand, for example, the main drivers of meteorological droughts. This is particularly relevant in order to compare local populations' perception of climate variables with quantitative estimates. Events above and below the long-term rainfall average distribution were studied in conjunction with intra-annual precipitation analysis. To complement this, we analysed river discharge regimes, as precipitation anomalies could be translated into hydrological droughts, thus generating a water resource imbalance, reduced groundwater levels, reservoir depletion, etc. (Liu et al., 2016). Secondly, considering the increasing number of heat waves that occurred during the past decade in Africa (Ceccherini et al., 2017), we 


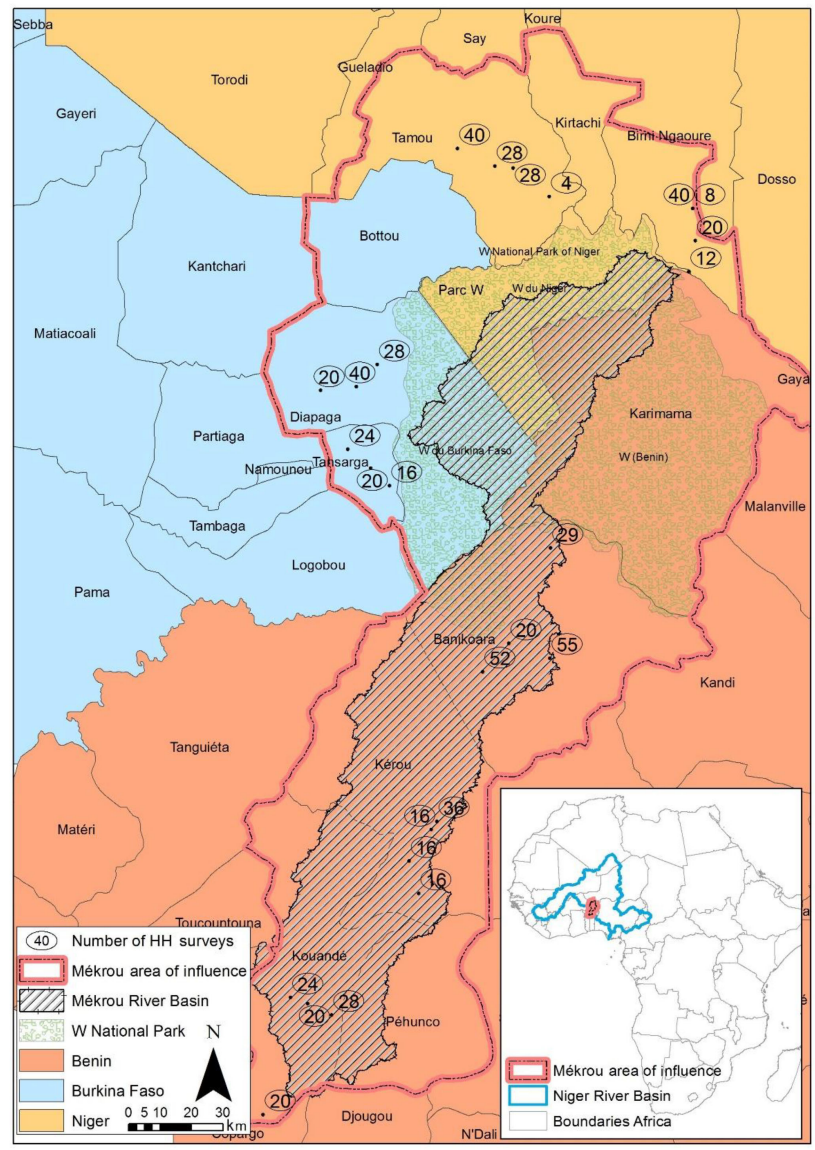

Figure 1. The Mékrou River basin and the household survey area (including number of questionnaires per village/town).

studied their magnitude and spatiotemporal evolution in the Mékrou area of influence to explain possible misperceptions that could arise in the surveys. The objective was to compare both precipitation and temperature stress with the survey results, offering empirical evidence of their concurrence or explaining the underlying causes of possible contrasting results.

\subsubsection{Precipitation pattern analysis}

Descriptive statistics of annual and seasonal rainfall were analysed jointly with the results of a seasonal Kendall (SK) test for monotonic trend applied to precipitation data derived from the Climate Hazards Group Infrared Precipitation with Station data v. 2.0 (hereafter CHIRPS). This database has a spatial resolution of $0.05^{\circ}$, corresponding to approximately $5 \mathrm{~km}$ (at the Equator), and covers all longitudes in the latitude range $50^{\circ} \mathrm{S}-50^{\circ} \mathrm{N}$, spanning a time horizon of 1981 to the present day (Funk et al., 2014). The SK test used is based on Hirsch and Slack (1984) and it was applied over two different time ranges: the entire time series (about 35 years) and the 10-year period considered in the household survey (2006-2015). The test is a modified version of the previous SK test proposed by Hirsch et al. (1982) and attempts to reduce the serial dependence of variables (given that seasonal precipitation data are serially correlated). Both are based on the non-parametric Mann-Kendall test (Mann, 1945; Kendall, 1975; Warren and Gilbert, 1987). The magnitude of trends are calculated using Sen's slope estimator and Kendall's tau as the rank correlation coefficient.

In addition, in order to identify precipitation anomalies, we calculated the Standardized Precipitation Index (hereafter SPI) proposed by McKee et al. (1993, 1995). The SPI measures the deviation of precipitation in a specific location from its long-term mean and is a widely used indicator for drought monitoring. This index could be applied over different timescales, each providing information about the impact of a given precipitation anomaly on the availability of water resources (WMO, 2012). In this study, the 3-month and 6-month SPIs (hereafter SPI-3 and SPI-6) were calculated, associated, respectively, with meteorological and agricultural droughts. A shorter SPI timescale is considered to be a good indicator of variations in soil moisture, while longer scales (up to 24 months) could be associated with groundwater or reservoir variations (WMO, 2012). For the purpose of this paper, as the Mékrou communities' economy is mainly based on rain-fed agriculture, we focused on the precipitation anomalies during the wet season, presenting the SPI-3 for the period June-August (JJA) and the SPI-6 for the period April to September (AMJJAS). The results are given in units of standard deviation (SD), indicating how far a given precipitation event is below (drier events are associated with a negative SD) or above (wetter event, positive SD) the long-term normal distribution of the precipitation observations in a given location. SPI values of around zero indicate a precipitation event in line with the long-term precipitation of the specific period, while negative (positive) values indicate precipitation levels below (above) historical values. SPI values could then be interpreted following a classification scheme where standard deviations are categorised into different classes, each associated with different levels of wet or dry anomalies. In this case we have divided the values following the seven categories proposed by Agnew (2000), where previous thresholds defined by McKee et al. (1993) were replaced by alternative classes (Table 3). Finally, in order to get a general overview of the anomalies in the different administrative units, we calculated the area percentage affected by each class over the entire time series.

\subsubsection{Heat wave analysis}

Russo et al. (2015) defined the daily Heat Wave Magnitude Index (HWMI) as the maximum magnitude of the heat waves in a year, where a heat wave is defined as a period equal to or greater than 3 consecutive days with maximum temperature above a daily threshold calculated for a 30-year reference period. The index is based on daily maximum temperatures, 
Table 3. Standardized Precipitation Index (SPI) categorisation and associated probability of occurrence (Agnew 2000).

\begin{tabular}{lrl}
\hline SPI & $\begin{array}{r}\text { Probability } \\
\text { of occurrence }\end{array}$ & Class \\
\hline$>1.65$ & 0.05 & Extremely wet \\
$1.28 / 1.64$ & 0.1 & Severely wet \\
$0.84 / 1.27$ & 0.2 & Moderately wet \\
$-0.84 / 0.84$ & 0.5 & Normal \\
$-1.28 /-0.83$ & 0.2 & Moderate drought \\
$-1.65 /-1.27$ & 0.1 & Severe drought \\
$<-1.65$ & 0.05 & Extreme drought \\
\hline
\end{tabular}

taking the intensity and duration of the event into account. In our case, the source used to retrieve the maximum daily temperatures is the ERA-Interim reanalysis dataset (Berrisford et al., 2011; Dee et al., 2011) available from 1979 onwards, with an approximate spatial resolution of $80 \mathrm{~km}$ at the Equator. The index was applied to study these events for the past 35 years across the study area.

\subsubsection{Discharge in the Mékrou River}

In order to have a quantitative estimation of water availability within the Mékrou River basin, the hydrological model SWAT (Neitsch et al., 2011) was set up and calibrated to assess annual and monthly river discharge. The SWAT model integrates all relevant ecohydrological processes, including water flow, surface runoff, percolation, lateral flow, groundwater flow, evapotranspiration, transmission losses, nutrient transport and turnover, vegetation growth, land use, and water management. SWAT sub-basins were delineated using the ArcSWAT interface with a digital elevation model of $90 \mathrm{~m}$ spatial resolution, resulting in 32 sub-basins for the whole area.

The historical discharge data recorded at the Barou gauge station (outlet of the river basin) and at the Kompoungou gauge station (a draining area that accounts for about $56 \%$ of the river basin) were used for model calibration. Lack of data availability represents a huge limitation for the hydrological analysis of the basin. In addition, these discharge observations are incomplete, as they are only available for a limited number of years (1990-2000 for Barou and 20042013 for Kompoungou). We used the SWAT-CUP program and manual setup to calibrate the outflow of the two monitoring stations and obtained satisfactory efficiency statistics (Moriasi et al., 2007) at monthly scales. In Barou, the NSE (Nash-Sutcliffe model efficiency coefficient; Nash and Sutcliffe, 1970) is 0.87 and linear regression $R^{2}$ is 0.88 , and in Kompoungou the NSE is 0.77 and $R^{2}$ is 0.71 . We used the SWAT-modelled discharges to consider an extended time period, required in particular to take into account climate variability and to cover areas of the basin where observations are not available.

\section{Results}

\subsection{Biophysical variables: precipitation, temperature, and river discharge}

\subsubsection{Precipitation patterns}

Mean annual precipitation in the study area varies from $500 \mathrm{~mm}$ in the northern administrative units (Bottou, Tamou, Kirtachi, and Falmey), to a maximum of about 1000$1300 \mathrm{~mm}$ upstream in the southern portion of the basin (Kouandé, Kérou, and Banikoara; Supplement Fig. S1). Generally, rainfall is highly variable in time and space and follows a cyclical trend of wet and dry periods. The mean monthly precipitation for the wettest month (August) in the southern and northern regions varies between 200 and $300 \mathrm{~mm}$, respectively, with the driest months (NovemberFebruary) being close to zero.

Comparing the precipitation patterns of a short (20072016) and a long period (1981-2006), it was possible to identify a slight decrease in rainfall during August and September, while a moderate increase was detected during June and July (Fig. 2). However, long- and short-term seasonal Kendall analyses, performed at a significance level $\alpha=5 \%$, were not able to identify any significant trend (Fig. 2). Some spatial differences were identified analysing the last 10 years of the study: in that regard, negative slopes were detected in the southern regions of Benin.

\subsubsection{Precipitation stress analysis}

The results of the SPI-3 and SPI-6 analyses highlighted a period of moderate to extreme droughts during the earlier part of the 1980s; this could also be seen in mean monthly precipitation values, where the overall rainfall from 1981 to 1985 is noticeably less than the long-term average (Fig. 3). After this period, the positive and negative anomalies were found to be more erratic, presenting alternate series of positive and negative events, such as some severe wet anomalies in the southern regions in 2003 and drought events in northern regions in 1997. Regarding the last 10 years of the study period, only a few drought anomalies affected at least $40 \%$ of the administrative areas. The northern portion of the basin in Niger (communes of Tamou and Kirtachi) was affected by a moderate to severe drought event during 2011, while in 2014 a similar event hit the southern portion of the basin in Benin (Banikoara, Kérou, Pehúnco, and Kouandé). In contrast, severe to extremely wet anomalies were predominantly recorded during the years 2003, 2005, and 2007 in the entire Mékrou area of influence. Summarising the results derived from the analysis of the SPI, we found that the decade considered in the household survey was mainly characterised by precipitation in line with the long-term average. The anomalies were not particularly intense and most frequently related to wet conditions when considering the mete- 


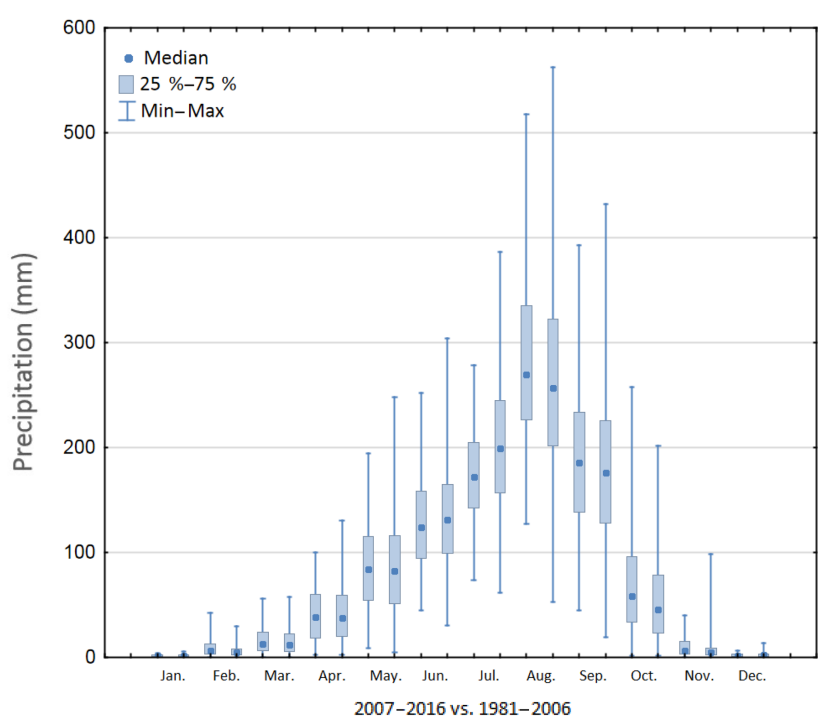

Figure 2. Box-whisker plot comparison (top) of monthly precipitation for the first 25 years of the time series versus the last 10 years (2007-2016 vs. 1981-2006). On the bottom, the results of the seasonal Mann-Kendall (MK) test for detecting significant increasing or decreasing trends (Kendall score) in the precipitation patterns for each of the areas taken into consideration in this study. The MK test was conducted using the observed precipitation records of the most recent time period (2007-2016) and the full time series available (1981-2016). The test performed did not highlight statistically significant (significance threshold $p$ value $<0.010$ ) increasing or decreasing trends in the analysis of the two precipitation time series.

orological precipitation stress indicator (SPI-3: 18 wet versus 15 dry anomalies), while a predominance of dry conditions was recorded when considering the agricultural precipitation stress (SPI-6: 17 dry versus 14 wet anomalies) (Figs. S2 and S3).

\subsubsection{Heat waves}

The spatiotemporal evolution of the HWMI between 1981 and 2015 is represented in Fig. 4. Despite some isolated events during 1987-1988 and some extremes in 1998, the analysis highlighted a constantly increasing trend in the heat wave magnitude, starting in 2004. The spatial pattern, however, is not clear, as the whole Mékrou area of influence was affected. In 2005, the HWMI was found to be higher in the central and northern parts of the basin, while the highest values in 2006 were recorded in the southern part and in 2010 in the northern part (Figs. S4 and S5).

In the period under consideration, mean annual temperature ranged between about $30^{\circ} \mathrm{C}$ in the north to $26.5^{\circ} \mathrm{C}$ in the south. April was the warmest month, with a maximum temperature of $40^{\circ} \mathrm{C}$ in the north and $35^{\circ} \mathrm{C}$ in the south. Minimum temperature in the coldest month (September) ranged between $19^{\circ} \mathrm{C}$ in the north and $15^{\circ} \mathrm{C}$ in the south, presenting the semi-arid region the highest range of variation of about $25^{\circ} \mathrm{C}$.

\subsubsection{River water flow trends}

The annual river discharge resulting from model simulation for the period 1995-2012 is presented in Fig. 5. The first 5 years of the simulation period (1990-1994) were discarded to consider an adequate model spin-up period.

Modelled discharge in the period under consideration averaged around $24 \mathrm{~m}^{3} \mathrm{~s}^{-1}$, corresponding to an average annual water flow of about $760 \mathrm{Mm}^{3}$ (ranging from 190 to $1400 \mathrm{Mm}^{3}$ in 1997 and 2008, respectively). The spatial distribution of the water resources follows the topography of the basin, making the headwaters (where annual discharge remains below $100 \mathrm{Mm}^{3}$ ) particularly subject to inter- and intra-annual variability (Fig. S7). High annual variability of the river discharge is an important issue for the sustainable water use in the basin, especially considering that agriculture is the main economic activity and the lack of water storage infrastructures in the basin. Intra-annual discharge variability in the Mékrou River basin follows the seasonal precipitation patterns: most abundant flows are reached after the rainy season (July-November), with the peak flow being reached in the period August-September-October (Fig. S6).

The analysis of the simulated river flows highlighted the large interannual variability of the discharge. In about 8 of the 18 years under consideration, the average discharge was estimated to be below the long-term average by more than $20 \%$, while in four instances the simulated discharge was estimated to exceed the average by more than $20 \%$ (Fig. 5). Although the analysis of the river discharge saw daily values with unusually high river discharge with respect to the average, we were not able to estimate the possible number of flood events in the domain of the study due to lack of data about flood propagation during historical events and detailed topography.

\subsubsection{Analysis of the population perception on the occurrence of extreme events and climate variability}

The household representatives gave their personal opinions on the occurrence of specific extreme events in the Mékrou River basin during the last 10 years of the study period (2006-2015) (Table 4). The selection of this 10-year framework allows for a relatively mid-term assessment of past climatic events. Regarding the occurrence of droughts, $86.8 \%$ of the households declared an increasing trend in the period under consideration. This percentage is lower in Niger, but still quite high $(71.5 \%)$. In addition, the vast majority of the local population $(88.5 \%)$ estimated that the levels of rainfall decreased during the last 10 years of the study period. This result is particularly evident in Benin and Burkina Faso (93.7 and $95.3 \%$, respectively). Not only did the rainfall de- 


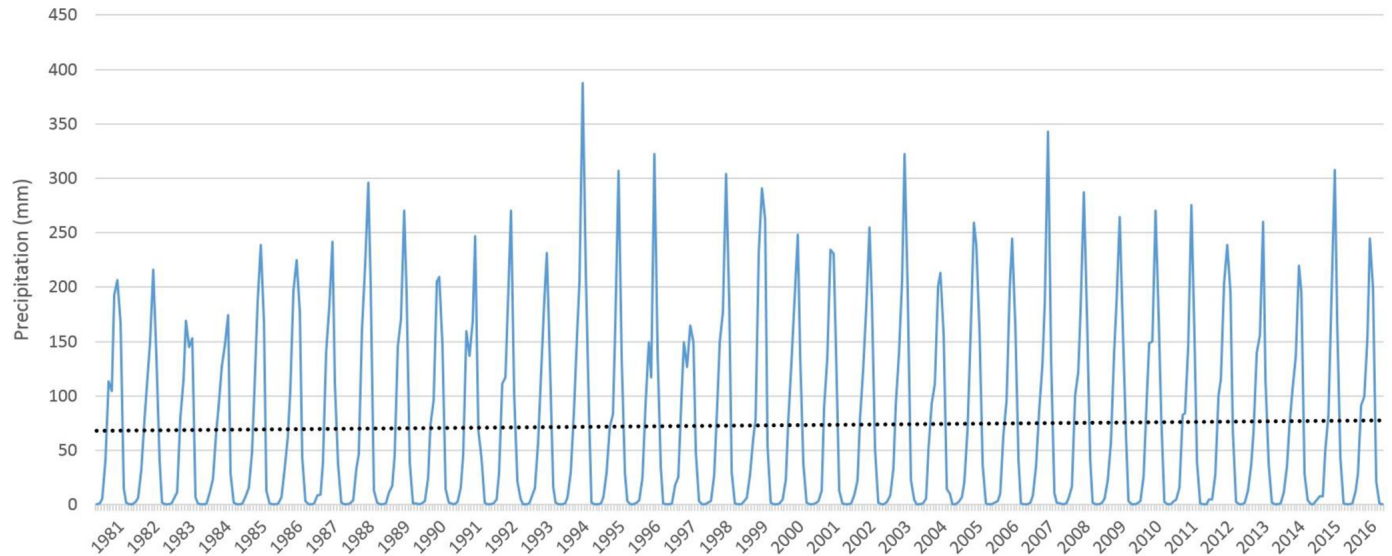

Figure 3. Temporal monthly precipitation profile for the Mékrou area of interest.

HWMI
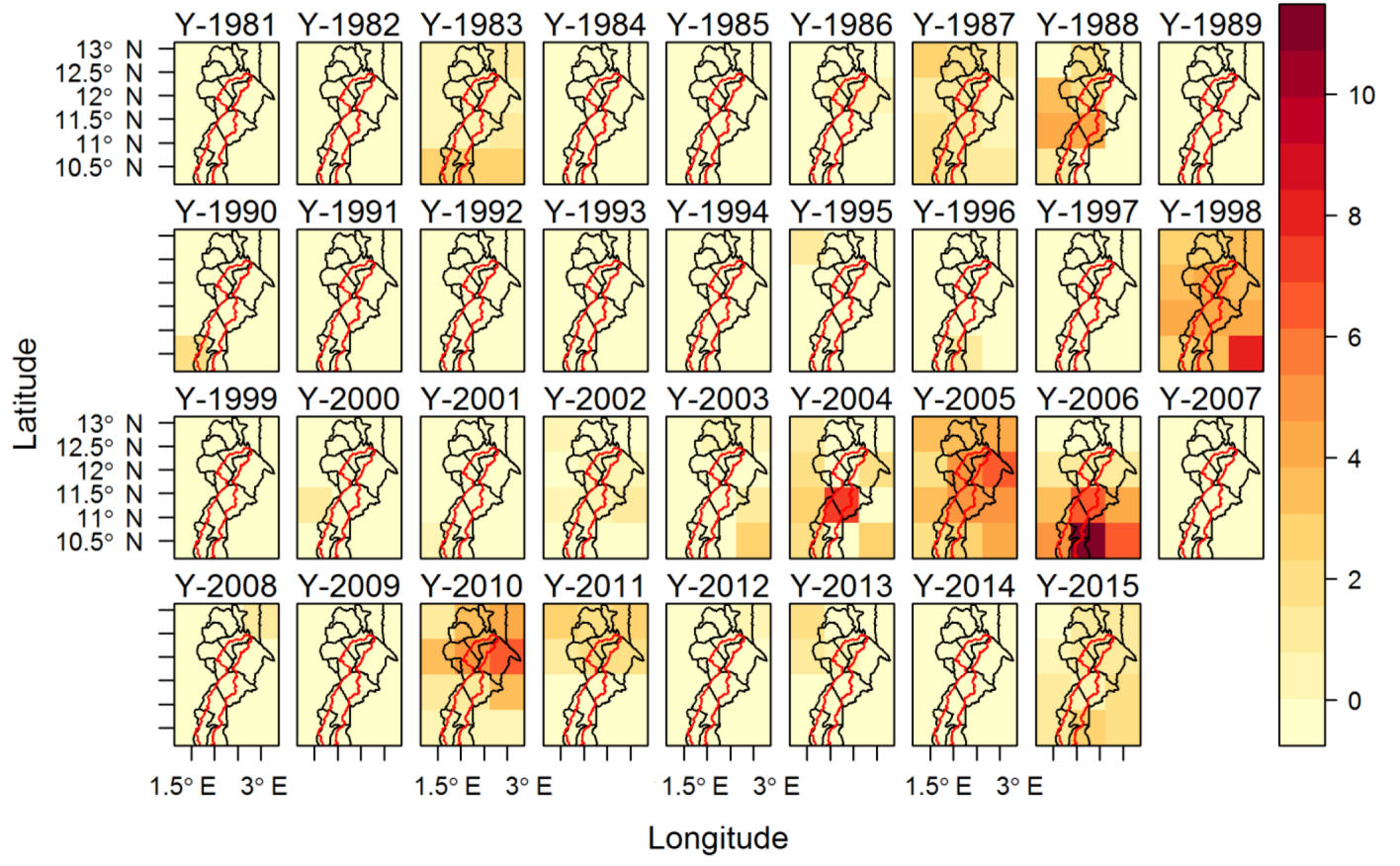

Figure 4. HWMI computed for 1981 to 2015 for the Mékrou River area.

crease but, according to the local population (92.7\%), the seasonal distribution also changed. In fact, the majority of the respondents $(83 \%)$ stated that the rainy season started with a delayed onset during the last 10 years of the study period, whereas almost all respondents $(91.8 \%)$ declared an earlier end to the season. Regarding heat waves, $76 \%$ of the interviewed population (62\% in Benin) stated that periods of intense heat waves became longer during the last 10 years of the study period. Regarding the number of events experienced, an increasing number of drought events were recorded, with a general frequency of 0 to 6 events. On average, the local population experienced in average 3.93 drought events when considering the whole Mékrou River basin (Table 3). The number is higher in Burkina Faso (4.8 events) and slightly lower in Niger (3.4 events).

Concerning flood events, opinions are less homogeneous over the whole Mékrou area. The majority (62\%) of the respondents stated that flood frequency did not increase over the last 10 years of the study period. This trend is quite heterogeneous among the three countries: $84.9 \%$ of the households in Benin agreed with the majority, while the responses are discordant in Burkina Faso, and $72.2 \%$ of the respondents in Niger found an increasing flood frequency in the period under consideration. When asked about the number 
Table 4. Observed climatic changes during the last 10 years of the study period: 2006-2015.

\begin{tabular}{|c|c|c|c|c|c|c|c|c|}
\hline & \multicolumn{2}{|l|}{ Benin } & \multicolumn{2}{|c|}{ Burkina Faso } & \multicolumn{2}{|l|}{ Niger } & \multicolumn{2}{|c|}{ Mékrou basin } \\
\hline & Count & $\%$ & Count & $\%$ & Count & $\%$ & Count & $\%$ \\
\hline \multicolumn{9}{|c|}{ Change of the rainfall quantity } \\
\hline No change & 8 & $2.4 \%$ & & & 4 & $2.2 \%$ & 12 & $1.8 \%$ \\
\hline Less rain & 311 & $93.7 \%$ & 141 & $95.3 \%$ & 132 & $73.3 \%$ & 584 & $88.5 \%$ \\
\hline More rain & 13 & $3.9 \%$ & 7 & $4.7 \%$ & 44 & $24.4 \%$ & 64 & $9.7 \%$ \\
\hline Total responses & 332 & & 148 & & 180 & & 660 & \\
\hline \multicolumn{9}{|c|}{ Distribution of the rainfall in the year } \\
\hline No change & 21 & $6.3 \%$ & & & 4 & $2.2 \%$ & 25 & $3.8 \%$ \\
\hline Better distribution & 16 & $4.8 \%$ & 2 & $1.4 \%$ & 5 & $2.8 \%$ & 23 & $3.5 \%$ \\
\hline Worse distribution & 295 & $88.9 \%$ & 146 & $98.6 \%$ & 171 & $95.0 \%$ & 612 & $92.7 \%$ \\
\hline Total responses & 332 & & 148 & & 180 & & 660 & \\
\hline \multicolumn{9}{|c|}{ More frequent droughts } \\
\hline Yes & 297 & $89.5 \%$ & 147 & $99.3 \%$ & 128 & $71.5 \%$ & 572 & $86.8 \%$ \\
\hline No & 35 & $10.5 \%$ & 1 & $0.7 \%$ & 51 & $28.5 \%$ & 87 & $13.2 \%$ \\
\hline Total responses & 332 & & 148 & & 179 & & 659 & \\
\hline \multicolumn{9}{|c|}{ More frequent floods } \\
\hline Yes & 50 & $15.1 \%$ & 76 & $51.4 \%$ & 130 & $72.2 \%$ & 256 & $38.8 \%$ \\
\hline No & 282 & $84.9 \%$ & 72 & $48.6 \%$ & 50 & $27.8 \%$ & 404 & $61.2 \%$ \\
\hline Total responses & 332 & & 148 & & 180 & & 660 & \\
\hline \multicolumn{9}{|c|}{ Delay in the start of the rainy season } \\
\hline Yes & 248 & $74.7 \%$ & 139 & $93.9 \%$ & 161 & $89.4 \%$ & 548 & $83.0 \%$ \\
\hline No & 84 & $25.3 \%$ & 9 & $6.1 \%$ & 19 & $10.6 \%$ & 112 & $17.0 \%$ \\
\hline Total responses & 332 & & 148 & & 180 & & 660 & \\
\hline \multicolumn{9}{|c|}{ Rainy season finishes earlier } \\
\hline Yes & 293 & $88.3 \%$ & 146 & $98.6 \%$ & 163 & $92.6 \%$ & 602 & $91.8 \%$ \\
\hline No & 39 & $11.7 \%$ & 2 & $1.4 \%$ & 13 & $7.4 \%$ & 54 & $8.2 \%$ \\
\hline Total responses & 332 & & 148 & & 176 & & 656 & \\
\hline \multicolumn{9}{|c|}{ Periods of extreme heat } \\
\hline No change & 34 & $10.2 \%$ & 10 & $6.8 \%$ & 15 & $8.5 \%$ & 59 & $9.0 \%$ \\
\hline Shorter & 75 & $22.6 \%$ & 7 & $4.7 \%$ & 17 & $9.7 \%$ & 99 & $15.1 \%$ \\
\hline Longer & 223 & $67.2 \%$ & 131 & $88.5 \%$ & 144 & $81.8 \%$ & 498 & $75.9 \%$ \\
\hline Total responses & 332 & & 148 & & 176 & & 656 & \\
\hline
\end{tabular}

of flood events experienced, almost one-third of the families stated that no flood events had occurred. The remaining replies are mostly distributed among one $(23.3 \%)$, two $(17.4 \%)$, and three $(13.1 \%)$ events. As for the change in the frequency of the events, this varied across the three countries. In Benin, $60.7 \%$ of the population did not experience any flood during the last 10 years of the study period. Large numbers of flood events were recorded primarily in Niger, followed by Burkina Faso (Table 5). In Benin, an average of only 0.7 flood events was declared during the last 10 years of the study period, while the average was 1.8 in Burkina Faso and 3.5 in Niger. The combination of these results sug- gests that the Niger portion of the Mékrou River basin was the most prone to flood events in the period under consideration. Regarding both flood and drought events, the perceptions are heterogeneous across the three countries in the basin, with no difference based on different socioeconomic characteristics. This could be explained by the homogeneity of the socioeconomic characteristics within the basin across three countries. 


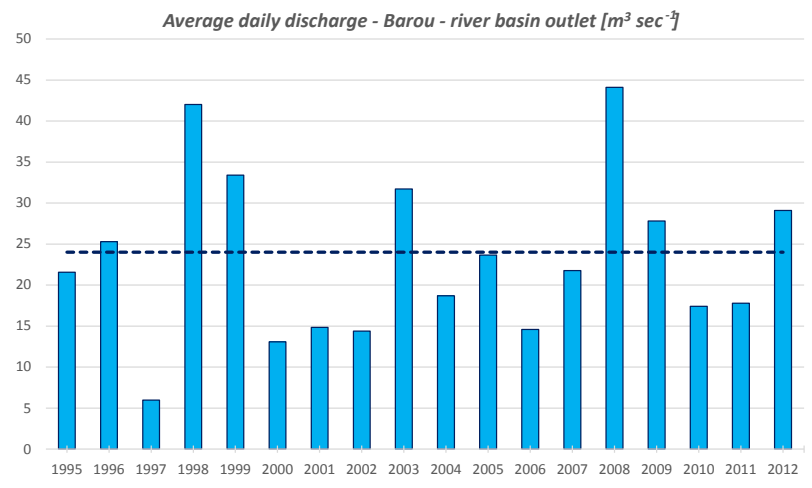

Figure 5. Daily average discharge of the Mékrou River at the Barou station, as modelled using SWAT for the period 1995-2012. The dashed line indicates the average of the total period under consideration.

Table 5. Statistical analysis of reported number of floods and droughts during the last 10 years.

\begin{tabular}{lllll}
\hline & $\begin{array}{l}\text { Mékrou } \\
\text { basin }\end{array}$ & Benin & $\begin{array}{l}\text { Burkina } \\
\text { Faso }\end{array}$ & Niger \\
\hline \multicolumn{5}{c}{ Floods } \\
\hline Mean & 1.69 & 0.73 & 1.78 & 3.46 \\
SD & 2.07 & 1.16 & 1.43 & 2.64 \\
\hline \multicolumn{5}{c}{ Droughts } \\
\hline Mean & 3.93 & 3.83 & 4.80 & 3.36 \\
SD & 2.83 & 2.95 & 2.72 & 2.49 \\
\hline
\end{tabular}

\subsection{Household results regarding flood and drought mitigation measures}

This section provides an empirical analysis of the household mitigation measures. The respondents chose among 13 mitigation strategies aimed at coping with changes in temperature and rainfall patterns. Eight of the original 13 strategies were considered to be negligible due to a positive response rate lower than $10 \%$, including practicing off-season agriculture, application of more intensive irrigation, raising less livestock in order to increase crops, raising fewer small ruminants and switching to more cattle, raising less cattle and switching to camels, raising less sheep and switching to goats, adoption of specific techniques to regenerate the necessary grass cover for the livestock, and rent or mortgage land.

The mitigation measures that recorded a positive a response rate greater than $10 \%$ are change of crop seeds, terracing the soil or using other methods to protect against erosion, planting more trees, emigration of at least one household member, and increasing the practice of non-agricultural activities as sources of revenue (Table 6). Changing crop seeds is quite a common strategy for adapting to rainfall changes and is widely applied in Burkinabe and Niger areas (for around 60-65\% of respondents) and, to a lesser, extent in Benin (34\%). The practice of terracing the soil to prevent erosion is mostly applied in the Beninese part of the Mékrou River basin. The planting of more trees is a common adaptation practice across the basin due to both changes in precipitation $(31 \%)$ and changes in temperature $(20 \%)$. Emigration appears as an adaptation strategy to mitigate the economic losses resulting from the impacts of changes in rainfall patterns. Around $25 \%$ of households saw one of their members emigrating due to temperature and rainfall changes; $16.4 \%$ of Beninese respondents stated that at least one member emigrated in the last 10 years of the study period due to rainfall changes. Finally, an important number of households, primarily in Benin (around 35\%) and in Niger (around 15\%), increasingly practice non-agricultural activities as sources of revenue to cope with the loss of income due to both rainfall and temperature changes.

\subsection{Flood and drought impacts and their cost assessment}

The local population of the Mékrou River basin also indicated the occurrence of extreme events during the 2-year period 2014-2015. The relatively recent occurrence of these events, some of which are still ongoing, allows for a more accurate estimation of the impacts and associated costs. Only a small percentage of the respondents (68 out of the total 660 interviewed households) stated that they had experienced any flood occurrence during the 2 years (Table 7). However, the occurrence of events differs between the three countries, with most of the events being reported in Burkina Faso (34.5\% of households affected by floods). Aligning with the frequency of reported events, the impacts of floods are proportionally more common in Burkina Faso. The most commonly reported impacts are the loss of agricultural production, damage to houses, and loss of livestock (Table 8).

The same analysis was applied for recent drought events. The vast majority $(76.7 \%)$ stated that they had not experienced any drought event during the last 2 years of the study period. However, more droughts are reported compared to floods, with 152 of the total 660 households interviewed experiencing an extreme drought event. Similarly, the occurrence of droughts is heterogeneous across the three countries. Droughts are less prominent in Niger (Table 7), where only a few droughts were reported, while a quarter of the population in Benin had experienced droughts during the last 2 years of the study period. In Burkina Faso, almost half of the households had experienced droughts during the 2-year period. The impacts of the recent drought were mostly recorded in Burkina Faso and Benin (Table 8), presenting a different profile. In Burkina Faso the impacts were exclusively manifested as losses of agricultural production, while in Benin most of the impact of the recent droughts was felt in the loss of agricultural production as well as malnutrition and loss 
Table 6. Household mitigation measures.

\begin{tabular}{|c|c|c|c|c|c|c|c|c|}
\hline \multicolumn{3}{|c|}{ Benin } & \multicolumn{2}{|c|}{ Burkina Faso } & \multicolumn{2}{|l|}{ Niger } & \multicolumn{2}{|c|}{ Mékrou basin } \\
\hline & Count & $\%$ & Count & $\%$ & Count & $\%$ & Count & $\%$ \\
\hline \multicolumn{9}{|c|}{ Change of crop seeds } \\
\hline \multicolumn{9}{|c|}{ Action taken due to temperature } \\
\hline Yes & 50 & $16.2 \%$ & 29 & $19.6 \%$ & 5 & $2.8 \%$ & 84 & $13.2 \%$ \\
\hline No & 259 & $83.8 \%$ & 119 & $80.4 \%$ & 175 & $97.2 \%$ & 553 & $86.8 \%$ \\
\hline \multicolumn{9}{|c|}{ Action taken due to rainfall } \\
\hline Yes & 110 & $34.0 \%$ & 99 & $66.9 \%$ & 110 & $61.1 \%$ & 319 & $48.9 \%$ \\
\hline No & 214 & $66.0 \%$ & 49 & $33.1 \%$ & 70 & $38.9 \%$ & 333 & $51.1 \%$ \\
\hline \multicolumn{9}{|c|}{ Terracing the soil or using other methods to protect against erosion } \\
\hline \multicolumn{9}{|c|}{ Action taken due to rainfall } \\
\hline Yes & 77 & $23.8 \%$ & 26 & $17.6 \%$ & 19 & $10.6 \%$ & 122 & $18.7 \%$ \\
\hline No & 247 & $76.2 \%$ & 122 & $82.4 \%$ & 161 & $89.4 \%$ & 530 & $81.3 \%$ \\
\hline \multicolumn{9}{|c|}{ Plantation of more trees } \\
\hline \multicolumn{9}{|c|}{ Action taken due to temperature } \\
\hline Yes & 84 & $27.2 \%$ & 33 & $22.3 \%$ & 8 & $4.4 \%$ & 125 & $19.6 \%$ \\
\hline No & 225 & $72.8 \%$ & 115 & $77.7 \%$ & 172 & $95.6 \%$ & 512 & $80.4 \%$ \\
\hline \multicolumn{9}{|c|}{ Action taken due to rainfall } \\
\hline Yes & 112 & $34.6 \%$ & 39 & $26.4 \%$ & 51 & $28.3 \%$ & 202 & $31.0 \%$ \\
\hline No & 212 & $65.4 \%$ & 109 & $73.6 \%$ & 129 & $71.7 \%$ & 450 & $69.0 \%$ \\
\hline \multicolumn{9}{|c|}{ Emigration of at least one household member } \\
\hline \multicolumn{9}{|c|}{ Action taken due to rainfall } \\
\hline Yes & 53 & $16.4 \%$ & 12 & $8.1 \%$ & 46 & $25.6 \%$ & 111 & $17.0 \%$ \\
\hline No & 271 & $83.6 \%$ & 136 & $91.9 \%$ & 134 & $74.4 \%$ & 541 & $83.0 \%$ \\
\hline \multicolumn{9}{|c|}{ Practicing more often non-agricultural activities as sources of revenue } \\
\hline \multicolumn{9}{|c|}{ Action taken due to temperature } \\
\hline Yes & 100 & $32.3 \%$ & 11 & $7.4 \%$ & 32 & $17.8 \%$ & 143 & $22.4 \%$ \\
\hline No & 210 & $67.7 \%$ & 137 & $92.6 \%$ & 148 & $82.2 \%$ & 495 & $77.6 \%$ \\
\hline \multicolumn{9}{|c|}{ Action taken due to rainfall } \\
\hline Yes & 119 & $36.6 \%$ & 14 & $9.5 \%$ & 20 & $11.1 \%$ & 153 & $23.4 \%$ \\
\hline No & 206 & $63.4 \%$ & 134 & $90.5 \%$ & 160 & $88.9 \%$ & 500 & $76.6 \%$ \\
\hline
\end{tabular}

of livestock. Both the flood and drought impacts recorded relate to general categories of impacts, mainly agriculture, livestock, and housing, as it was not feasible to collect more in-depth qualitative characteristics of the impacts.

The estimated flood costs to households differ among the three countries. The cost of the recent floods is highest in Burkina Faso (Table 9), where the average cost to an affected household is FCFA 334326 (West African francs) (approximately EUR 510 in 2017). The estimated flood costs in Benin and Niger are 40000 and FCFA 160000 , respectively. Furthermore, we observed a difficulty among the households in estimating the costs of the recent floods, especially in Benin and Niger (the less affected countries), where most of the affected households were not able to provide a cost estimation. Twenty out of 68 affected households in the basin were not able to provide a cost estimation of the floods they experienced. The average cost of the recent droughts, FCFA 256440 ( EUR 391), was almost the same in Burkina Faso and in Benin (Table 9) and was lower than the average cost of the recent floods. Again, it is evident that households found it difficult to estimate the costs of the recent droughts, especially in Benin where the majority (61 out of the 152 
Table 7. Experienced extreme flood events during the last 2 years (2014-2015).

\begin{tabular}{|c|c|c|c|c|c|c|c|c|}
\hline & \multicolumn{2}{|l|}{ Benin } & \multicolumn{2}{|c|}{ Burkina Faso } & \multicolumn{2}{|l|}{ Niger } & \multicolumn{2}{|c|}{ Mékrou basin } \\
\hline & Count & $\%$ & Count & $\%$ & Count & $\%$ & Count & $\%$ \\
\hline \multicolumn{9}{|c|}{ Floods } \\
\hline Yes & 9 & $2.7 \%$ & 51 & $34.5 \%$ & 8 & $4.4 \%$ & 68 & $10.3 \%$ \\
\hline No & 322 & $97.3 \%$ & 97 & $65.5 \%$ & 172 & $95.6 \%$ & 591 & $89.7 \%$ \\
\hline \multicolumn{9}{|c|}{ Droughts } \\
\hline Yes & 83 & $25.5 \%$ & 66 & $44.9 \%$ & 3 & $1.7 \%$ & 152 & $23.3 \%$ \\
\hline No & 243 & $74.5 \%$ & 81 & $55.1 \%$ & 177 & $98.3 \%$ & 501 & $76.7 \%$ \\
\hline
\end{tabular}

Table 8. Impacts of extreme floods and droughts to the households.

\begin{tabular}{|c|c|c|c|c|}
\hline & Benin & $\begin{array}{r}\text { Burkina } \\
\text { Faso }\end{array}$ & Niger & $\begin{array}{r}\text { Mékrou } \\
\text { basin }\end{array}$ \\
\hline & Count & Count & Count & Count \\
\hline \multicolumn{5}{|c|}{ Impacts of floods } \\
\hline Damage to the house & 3 & 24 & 5 & 32 \\
\hline $\begin{array}{l}\text { Loss of agricultural } \\
\text { production }\end{array}$ & 8 & 44 & 7 & 59 \\
\hline $\begin{array}{l}\text { Injury or death of } \\
\text { a household member }\end{array}$ & & 1 & 3 & 4 \\
\hline Loss of livestock & & 16 & 4 & 20 \\
\hline \multicolumn{5}{|c|}{ Impacts of droughts } \\
\hline $\begin{array}{l}\text { Loss of agricultural } \\
\text { production }\end{array}$ & 74 & 66 & 3 & 143 \\
\hline $\begin{array}{l}\text { Malnutrition of at least } \\
\text { one household person }\end{array}$ & 41 & 4 & 2 & 47 \\
\hline Loss of livestock & 20 & 4 & 3 & 27 \\
\hline
\end{tabular}

Table 9. Estimated costs of the recent flood and droughts (in FCFA).

\begin{tabular}{lrrrr}
\hline & $\begin{array}{c}\text { Mékrou } \\
\text { basin }\end{array}$ & Benin & $\begin{array}{r}\text { Burkina } \\
\text { Faso }\end{array}$ & Niger \\
\hline \multicolumn{6}{c}{ Costs of floods } \\
\hline Mean & $324563(\sim$ EUR 495) & 40000 & 334326 & 160000 \\
SD & 373159 & & 378071 & \\
\hline \multicolumn{5}{c}{ Costs of droughts } \\
Mean & $256440(\sim$ EUR 391) & 262184 & 252803 & 0 \\
SD & 324224 & 257676 & 362150 & 0 \\
\hline
\end{tabular}

households) of the affected households were not able to provide a cost estimation. Regarding the geographical differentiation of the cost of both floods and droughts, heterogeneity is observed among the three countries but not within the countries where costs are homogenous among the selected villages and towns. Also, the small sample of the households affected by floods and droughts is insufficient for statistical aggregation to the total population of the basin.

\subsection{An econometric analysis to identify variables that influence the costs of floods and droughts}

In addition to the statistical estimation of the cost of floods and droughts, two econometric models were developed to provide an analysis of costs based on socioeconomic and other relative factors. A wide series of independent variables of the household, such as socioeconomic conditions and mitigation measures, was used to find the determinants of the cost of extreme events and to analyse the cost of floods and droughts. Using several regression models and a combination of independent variables, two models were set up that exclusively included statistically significant independent variables ( $p$ value less than 0.05 , and in one case slightly higher than 0.05 but less than 0.1 ). Table 10 presents the total of the independent variables, including their scaling and correlation. The latter is important for the coherence of the multivariate models, since low correlation among the independent variables excludes the existence of multicollinearity.

Regarding floods, the multivariate regression model in Table 11 includes the self-stated economic status (ECONSTAT) of households as an independent variable and as a qualitative alternative to household income. The model reveals a strong economic status effect, meaning that the richer the household, the higher the economic impact of floods. The negative sign is due to the structure of the variable scaling (where 1 represents rich and 5 represents significantly poorer economic conditions than the other households). Two of the main flood impacts, loss of crop productivity (CropProdLoss) and loss of livestock (LivestockLoss), were also included in the model as independent variables and were found to be significant. According to the multivariate regression model, the average cost of floods per household during the flood events of the last 2 years of the study period (20142015) was equal to EUR 390.92. In order to avoid problems of multicollinearity, correlation among the independent variables was tested. The calculated Pearson's $R$ values, all be- 
Table 10. Selected independent variables for modelling costs of floods and droughts.

\begin{tabular}{|c|c|c|}
\hline Variable & Scaling & Correlation \\
\hline ECONSTAT & $\begin{array}{l}1 \text { - rich; } 2 \text { - relatively rich; } 3 \text { - average; } \\
4 \text { - below average; } 5 \text { - much worse } \\
\text { than average }\end{array}$ & $\begin{array}{l}\text { CropProdLoss: }-0.0786 \\
\text { LivestockLoss: }-0.134\end{array}$ \\
\hline CropProdLoss & 0 (no impact), 1 (impact) & LivestockLoss: -0.017 \\
\hline LivestockLoss & 0 (no impact), 1 (impact) & PRODCROP: 0.212 \\
\hline PRODCROP & Numerical value & \\
\hline
\end{tabular}

Table 11. Costs of floods - multivariate linear regression model.

\begin{tabular}{lrrr}
\hline Number of obs $=48 ;$ R-sq: 0.4828 & $F$ test: 7.842 & & \\
\hline Independent variables & Coef. & SE & $P>z$ \\
ECONSTAT & $-1285 \cdot 48.5$ & 47850.09 & 0.01 \\
CropProdLoss & 287269.9 & 129224.5 & 0.031 \\
LivestockLoss & 359272.4 & 92753.99 & 0 \\
cons & 429595.2 & 225058.3 & 0.063 \\
Cost estimate/household & 256441 (FCFA) & 390.92 (EUR) & \\
\hline
\end{tabular}

Table 12. Costs of droughts - multivariate linear regression model.

\begin{tabular}{lrrr}
\hline Number of obs =98; R-sq: 0.1907 & $F$ test: 11.196 & & \\
\hline Independent variables & Coef. & $\mathrm{SE}$ & $P>z$ \\
PRODCROP & 14.08 & 3.64 & 0 \\
LivestockLoss & 137261.8 & 74243.4 & 0.068 \\
cons & 130367.5 & 39952.2 & 0.002 \\
Cost estimate/household & 324563 (FCFA) & 495 (EUR) & \\
\hline
\end{tabular}

low the 0.3 threshold, suggest a low correlation among the independent variables.

Similarly, a multivariate regression model was applied to analyse the costs of droughts (Table 12). The independent variable related to loss of livestock was found to have a strong effect in this model too. However, drought costs are found to significantly depend on the total crop production of the households (PRODCROP). According to this regression model, the estimated cost of droughts per household that experienced drought events during the last 2 years of the study period (2014-2015) was EUR 494.76. Similarly low correlations were detected among the independent variables.

\section{Discussion and conclusions}

This paper combines the results of a household survey and climate data analysis to assess floods, droughts, and climate variability in the Mékrou River basin in West Africa. The opinions and perceptions of household representatives revealed strong climate variability over a 10 -year period (2006-2015). It is worth mentioning that $83 \%$ of the population noticed a delayed onset of the rainy season during this period. In addition, $91 \%$ of the population also observed an early end of the wet season. Moreover, $88.5 \%$ of the respondents reported a general reduction in precipitation during the 10 -year period under consideration, and $75.9 \%$ reported an increase in the magnitude and frequency of extreme heat events. This tendency is partially confirmed by the analysis of climatic variables, mainly based on precipitation and temperature data. The findings of the analysis confirmed the increase in both the frequency and magnitude of heat waves in the study area. The climatic variability was also found to be noticeably high, but the Mann-Kendall analysis failed to find statistically significant trends in the precipitation patterns. It was not possible to clearly identify a shift in the intra-annual temporal distribution of precipitation, as there was no indication of a slightly delayed onset nor an early end of the rainy season.

The survey-based findings revealed a substantial difference between the occurrence of floods and droughts. With regard to droughts, $86.8 \%$ of the population reported that dry periods were more frequent during the 10 years from 2006 to 2015, while $23.3 \%$ experienced an extreme drought event during the last 2 years (2014-2015), resulting in 3.93 extreme drought events on average. Fewer flood events than drought events were reported by the local population. More 
than $60 \%$ of the respondents stated that flood frequency did not change during the period 2006-2015, and only $10.3 \%$ of the population experienced an extreme flood event during the period 2014-2015 (1.69 extreme flood events on average per household). The perceptions of the local population were confirmed by the climatic factors regarding flood events. An analysis of extreme precipitation in the past 30 years did not report a significant increasing trend in the occurrence of flood events. Similar conclusions, but this time contrary to the impressions of the local population, were derived from the analysis of dry periods. This difference between perceived occurrence and observed droughts could be explained by the misperception of the local population confounding the observed increasingly frequent heat wave events with more frequent droughts. However, an analysis of the meteorological (SPI-3) and agricultural (SPI-6) drought indicators confirmed the occurrence of a number of dry periods that could be in line with those reported by the local population in the portion of the basin located within the borders of Benin and Niger. However, the analysis of the SPI failed to find any significant dry periods in the Beninese portion of the Mékrou River basin.

The household survey analysis reported important findings regarding the measures adopted by the households of the Mékrou River basin to mitigate floods and droughts. From a list of options, the most significant household mitigation measures were identified as being: changing crop seeds, planting more trees, and increased practice of nonagricultural economic activities, while, especially in Niger, a considerable part of the population emigrated due to the loss in agricultural production caused by the reduced rainfall. The findings regarding the impacts of floods and droughts and their costs are also interesting. For those households that experienced an extreme flood event during the period 2014-2015, the most frequent impacts were reported to be crop production losses, damages to houses, and loss of livestock. The loss of crop production, malnutrition, and the loss of livestock were the most important impacts of extreme droughts. In addition, the total cost per household of the impacts of extreme floods and droughts was estimated. The cost assessment is two-fold, based on the sample estimations and the application of two linear multivariate regression econometric models. The average cost of flood events in the period 2014-2015 was estimated at EUR 495 per affected household, based on the average declared losses. The average cost of extreme droughts was EUR 391 per household. This study confirmed the difficulty of estimating the costs of natural hazards at the household level, even in the case of recent events. A considerable percentage of household representatives (27\% for floods and $38 \%$ for droughts) were not able to provide an estimation of the costs of the extreme events that they recently experienced.

Regarding the methodological approach of this work, the combination of the household survey data analysis with the study of the climatic variables could provide an integrated assessment of floods and droughts, especially in cases such as the Mékrou River basin, where access to reliable information is very limited. The survey approach, in particular, could provide data at household level that could be used for a detailed qualitative and quantitative assessment of natural hazards, such as floods and droughts. Potential limitations of this approach are mainly the information biases and misperceptions of the local population, which could influence the objectivity of their responses. Furthermore, such a survey approach depicts the opinions within a specific time frame and, therefore, should be periodically repeated to better validate the findings. This would require increased financial and human resources. The major potential benefit of this approach is that it provides information to support decision-makers and local governments, leading to the more effective and efficient design of flood and drought mitigation policies and measures. Most often, natural hazards risk mitigation measures and policies use either climate modelling tools or socioeconomic analyses, but rarely combine both. In developing countries where information is limited, such a coupling approach could integrate local characteristics and perceptions into natural hazard planning policies in order to provide more efficient mitigation measures. More specifically, such an approach could be used by state and local authorities to design risk mitigation and prevention measures in the framework of transboundary river basin management plans or even design climate adaptation strategies combining climate and socioeconomic analysis while structuring national adaptation programmes of action (NAPAs).

Data availability. The data for this paper are part of an ongoing eu project. The Joint Research Centre of the European Commission has its own public database where all project data are published. However for the specific paper, the data are not yet published in the JRC database. Therefore in this phase it is not possible to provide a DOI or URL.

\section{The Supplement related to this article is available online at https://doi.org/10.5194/nhess-18-1279-2018- supplement.}

Author contributions. VM, CD, and CCM designed the household survey and analysed the data. FF, IA, MP, LM, and AA analysed the climate data. VM, CD, FF, and IA prepared the first draft of the manuscript. All authors discussed the results and commented on the manuscript at all stages.

Competing interests. The authors declare that they have no conflict of interest.

Special issue statement. This article is part of the special issue "Damage of natural hazards: assessment and mitigation". It is not associated with a conference. 
Acknowledgements. This work is a part of the "Water for Growth and Poverty Reduction in the Mékrou" project funded by the European Commission. This project is jointly implemented by the Joint Research Centre (JRC) and by the Global Water Partnership (GWP). The household survey referred to in this article was designed and implemented by the JRC and local universities in Benin, Niger, and Burkina Faso. Professor Karidia Sanon from the University of Ouagadougou (Burkina Faso) was the head of the Burkina Faso team as well as the general coordinator of the three African field teams. Euloge Agbossou and Yèkambèssoun N'Tcha M'Po from the National Water Institute (Institut National de l'Eau - INE) coordinated the Benin team, and Professor Boureima Ousmane from the Abdou Moumouni University of Niamey was the head of the Niger team. The authors would like to thank Ms. Grainne Mulhern (JRC) for proofreading the manuscript.

Edited by: Thomas Thaler

Reviewed by: three anonymous referees

\section{References}

Agnew, C. T.: Using the SPI to identify drought, Drought Netw. News, (12), 6-12, available at: https://digitalcommons.unl.edu/ cgi/viewcontent.cgi?referer=https://www.google.it/\&httpsredir= $1 \&$ article $=1000 \&$ context $=$ droughtnetnews, 2000.

Alfieri, L., Salamon, P., Pappenberger, F., Wetterhall, F., and Thielen, J.: Operational early warning systems for waterrelated hazards in Europe. Environ. Sci. Pol., 21, 35-49, https://doi.org/10.1016/j.envsci.2012.01.008, 2012.

Bader, J.-C., Belaud, G., Lamagat, J.-P., Ferret, T., and Vauchel, P.: Modélisation de propagation d'écoulement entre lits mineur et majeur sur les fleuves Sénégal et Niger, Hydrol. Sci. J., 1-20, https://doi.org/10.1080/02626667.2016.1148815, 2016.

Barrios, S., Bertinelli, L., and Strobl, E.: Trends in Rainfall and Economic Growth in Africa: A Neglected Cause of the African Growth Tragedy, Rev. Econ. Stat., 92, 350-366, https://doi.org/10.1162/rest.2010.11212, 2010.

Berlemann, M. and Wenzzel, D.: Long-term Growth Effects of Natural Disasters, Empirical Evidence for Droughts (No. 5598), CESIFO Working Paper Cat. 10: Energy and Climate Economics, 2015.

Berrisford, P., Dee, D., Poli, P., Brugge, R., Fielding, K., Fuentes, M., Kållberg, P., Kobayashi, S., Uppala, S., and Simmons, A.: The ERA-Interim archive Version 2.0, ERA Rep. Ser., available at: https://www.ecmwf.int/en/elibrary/ 8174-era-interim-archive-version-20, 2011.

Bouwer, L. M., Poussin, J., Papyrakis, E., Daniel, V. E., Pfurtscheller, C., Thieken, A. H., and Aerts, J. C. J. H.: Methodology report on costs of mitigation - CONHAZ Report, 2011.

Brower, R., Akter, S., Brander, L., and Haque, E.: Economic valuation of flood risk exposure and reduction in a severely flood prone developing country, Environ. Dev. Econ., 14, 397, https://doi.org/10.1017/S1355770X08004828, 2009.

Bubeck, P. and Kreibich, H.: Natural Hazards?: direct costs and losses due to the disruption of production processes - CONHAZ Report, 2011.
Cavallo, E.: Natural Disasters and the Economy - A Survey. Int. Rev. Environ. Resour. Econ., 5, 63-102, https://doi.org/10.1561/101.00000039, 2011.

Ceccherini, G., Russo, S., Ameztoy, I., Marchese, A. F., and Carmona-Moreno, C.: Heat waves in Africa 1981-2015, observations and reanalysis, Nat. Hazards Earth Syst. Sci., 17, 115125, https://doi.org/10.5194/nhess-17-115-2017, 2017.

Dee, D. P., Uppala, S. M., Simmons, A. J., Berrisford, P., Poli, P., Kobayashi, S., Andrae, U., Balmaseda, M. A., Balsamo, G., Bauer, P., Bechtold, P., Beljaars, A. C. M., van de Berg, L., Bidlot, J., Bormann, N., Delsol, C., Dragani, R., Fuentes, M., Geer, A. J., Haimberger, L., Healy, S. B., Hersbach, H., Hólm, E. V., Isaksen, L., Kållberg, P., Köhler, M., Matricardi, M., McNally, A. P., Monge-Sanz, B. M., Morcrette, J.-J., Park, B.-K., Peubey, C., de Rosnay, P., Tavolato, C., Thépaut, J.-N., and Vitart, F.: The ERA-Interim reanalysis: configuration and performance of the data assimilation system, Q. J. Roy. Meteor. Soc., 137, 553-597, https://doi.org/10.1002/qj.828, 2011.

Dell, M., Jones, B. F., and Olken, B. A.: What Do We Learn from the Weather? The New Climate-Economy Literature, J. Econ. Lit., 52, 740-798, https://doi.org/10.1257/jel.52.3.740, 2014.

Fitchett, E. J. A., Seale, A. C., Vergnano, S., Sharland, M., Heath, P. T., Saha, S. K., Agarwal, R., Ayede, A. I., Bhutta, Z. A., Black, R., Bojang, K., Campbell, H., Cousens, S., Darmstadt, G. L., Madhi, S. A., Meulen, A. S., Modi, N., Patterson, J., Qazi, S., Schrag, S. J., Stoll, B. J., Wall, S. N., Wammanda, R. D., and Lawn, J. E.: Strengthening the Reporting of Observational Studies in Epidemiology for Newborn Infection (STROBE-NI): an extension of the STROBE statement for neonatal infection research, Lancet Infect. Dis., 16, e202-e213, https://doi.org/10.1016/S1473-3099(16)30082-2, 2016.

Froidurot, S. and Diedhiou, A.: Characteristics of wet and dry spells in the West African monsoon system, Atmos. Sci. Lett., 18, 125131, https://doi.org/10.1002/asl.734, 2017.

Funk, C. C., Peterson, P. J., Landsfeld, M. F., Pedreros, D. H., Verdin, J. P., Rowland, J. D., Romero, B. E., Husak, G. J., Michaelsen, J. C., and Verdin, A. P.: A Quasi-Global Precipitation Time Series for Drought Monitoring: U.S. Geological Survey Data Series 832, 4 p., https://doi.org/10.3133/ds832, 2014.

Gautam, M.: Managing Drought in Sub-Saharan Africa: policy perspectives. Invited Paper Prepared for a Panel Session on Drought: Economic Consequences and Policies for Mitigation, in IAAE Conference, Gold Coast, Queensland, Australia, 2006.

Green, C., Viavattene, C., Thompson, P.: Guidance for assessing flood losses - CONHAZ Report, 2011.

Hallegatte, S.: A Cost Effective Solution to Reduce Disaster Losses in Developing Countries: Hydro-Meteorological Services, Early Warning, and Evacuation (No. 6058), World Bank Policy Research Working Paper, Washington DC, USA, 2012.

Halsnæs, K. and Trærup, S.: Development and Climate Change: A Mainstreaming Approach for Assessing Economic, Social, and Environmental Impacts of Adaptation Measures, Environ. Manage., 43, 765-778, https://doi.org/10.1007/s00267-009-9273-0, 2009.

Hellmuth, M. E., Moorhead, A., Thomson, M. C., and Williams, J., (Eds.): Climate Risk Management in Africa: Learning from Practice, International Research Institute for Climate and Society (IRI) - Columbia University, New York, USA, 
available at: https://iri.columbia.edu/wp-content/uploads/2013/ 07/Climate-and-Society-No1_en.pdf, 2007.

Hirsch, R. M. and Slack, J. R.: A Nonparametric Trend Test for Seasonal Data With Serial Dependence, Water Resour. Res., 20, 727-732, https://doi.org/10.1029/WR020i006p00727, 1984.

Hirsch, R. M., Slack, J. R., and Smith, R. A.: Techniques of trend analysis for monthly water quality data, Water Resour. Res., 18, 107-121, https://doi.org/10.1029/WR018i001p00107, 1982.

Hsiang, S. M.: Temperatures and cyclones strongly associated with economic production in the Caribbean and Central America, P. Natl. Acad. Sci., 107, 15367-15372, https://doi.org/10.1073/pnas.1009510107, 2010.

Kendall, M. G.: Rank correlation methods, Oxford Uni., New York, NY, USA, 1975.

Liu, X., Zhu, X., Pan, Y., Li, S., Liu, Y., and Ma, Y.: Agricultural drought monitoring: Progress, challenges, and prospects, J. Geogr. Sci., 26, 750-767, https://doi.org/10.1007/s11442-0161297-9, 2016

Logar, I. and van den Bergh, J.: Methods of Assessment of the Costs of Droughts - CONHAZ Report, 2011.

Luechinger, S. and Raschky, P. A.: Valuing flood disasters using the life satisfaction approach, J. Public Econ., 93, 620-633, https://doi.org/10.1016/j.jpubeco.2008.10.003, 2009.

Mann, H. B.: Nonparametric Tests Against Trend, Econometrica, 13, 245-259, https://doi.org/10.2307/1907187, 1945.

Markantonis, V., Meyer, V., and Lienhoop, N.: Evaluation of the environmental impacts of extreme floods in the Evros River basin using Contingent Valuation Method, Nat. Hazards, 69, 15351549, https://doi.org/10.1007/s11069-013-0762-3, 2013.

Markantonis, V., Meyer, V., and Schwarze, R.: Review Article "Valuating the intangible effects of natural hazards - review and analysis of the costing methods", Nat. Hazards Earth Syst. Sci., 12, 1633-1640, https://doi.org/10.5194/nhess-12-1633-2012, 2012.

Masih, I., Maskey, S., Mussá, F. E. F., and Trambauer, P.: A review of droughts on the African continent: a geospatial and long-term perspective, Hydrol. Earth Syst. Sci., 18, 3635-3649, https://doi.org/10.5194/hess-18-3635-2014, 2014.

McKee, T., Doesken, N., and Kleist, J.: Drought Monitoring with Multiple Time Scales, in 9th AMS Conference on Applied Climatology, Dallas, TX, USA, 1995.

McKee, T. B., Doesken, N. J., and Kleist, J.: The relationship of drought frequency and duration to time scales, Prepr. 8th Conf. Appl. Climatol., 179-184, 1993.

Moriasi, D. N., Arnold, J. G., Van Liew, M. W., Bingner, R. L., Harmel, R. D., and Veith, T. L.: Model Evaluation Guidelines for Systematic Quantification of Accuracy in Watershed Simulations, Trans. ASABE, 50, 885-900, https://doi.org/10.13031/2013.23153, 2007.

Nash, J. E. and Sutcliffe, J. V.: River flow forecasting through conceptual models part I - A discussion of principles, J. Hydrol., 10, 282-290, https://doi.org/10.1016/0022-1694(70)90255-6, 1970.

Neitsch, S. L., Arnold, J. G., Kiniry, J. R., and Williams, J. R.: Soil and Water Assessment Tool Theoretical Documentation, Texas Water Resour. Inst. Tech. Rep., 46, 647, available at: swat.tamu. edu/media/99192/swat2009-theory.pdf, 2009.

Ngigi, S. N., Savenije, H. H. G., Rockström, J., and Gachene, C. K.: Hydro-economic evaluation of rainwater harvesting and management technologies: Farmers' investment options and risks in semi-arid Laikipia district of Kenya, Phys. Chem. Earth, Parts
A/B/C, 30, 772-782, https://doi.org/10.1016/j.pce.2005.08.020, 2005.

Ologunorisa, T. E. and Adeyemo, A.: Public Perception of Flood Hazard in the Niger Delta, Nigeria, Environmentalist, 25, 39-45, https://doi.org/10.1007/s10669-005-3095-2, 2005.

Oyekale, A.: Access to Risk Mitigating Weather Forecasts and Changes in Farming Operations in East and West Africa: Evidence from a Baseline Survey, Sustainability, 7, 14599-14617, https://doi.org/10.3390/su71114599, 2015.

Rosegrant, M., Ximing, C., Cline, S., and Nakagawa, N.: The role of rain-fed agriculture in the future of global food production, EPTD - Environ. Prod. Technol. Div., 90, 2002.

Russo, S., Sillmann, J., and Fischer, E. M.: Top ten European heatwaves since 1950 and their occurrence in the coming decades, Environ. Res. Lett., 10, 124003, https://doi.org/10.1088/17489326/10/12/124003, 2015.

Schmitt, L., Graham, H., and White, P.: Economic Evaluations of the Health Impacts of Weather-Related Extreme Events: A Scoping Review, Int. J. Environ. Res. Public Health, 13, 1105, https://doi.org/10.3390/ijerph13111105, 2016.

Shiferaw, B., Tesfaye, K., Kassie, M., Abate, T., Prasanna, B. M., and Menkir, A.: Managing vulnerability to drought and enhancing livelihood resilience in sub-Saharan Africa: Technological, institutional and policy options, Weather Clim. Extrem., 3, 6779, https://doi.org/10.1016/j.wace.2014.04.004, 2014.

Shisanya, S. and Mafongoya, P.: Adaptation to climate change and the impacts on household food security among rural farmers in uMzinyathi District of Kwazulu-Natal, South Africa, Food Secur., 8, 597-608, https://doi.org/10.1007/s12571-016-0569-7, 2016.

Tarpanelli, A., Amarnath, G., Brocca, L., Massari, C., and Moramarco, T.: Discharge estimation and forecasting by MODIS and altimetry data in Niger-Benue River, Remote Sens. Environ., 195, 96-106, https://doi.org/10.1016/j.rse.2017.04.015, 2017.

Toya, H. and Skidmore, M.: Economic development and the impacts of natural disasters, Econ. Lett., 94, 20-25, https://doi.org/10.1016/j.econlet.2006.06.020, 2007.

UNISDR: Technical Guidance for Monitoring and Reporting on Progress in Achieving the Global Targets of the Sendai Framework for Disaster Risk Reduction 2015-2030, Geneva, Switzer land, 2017.

UNISDR: Global Assessment Report on Disaster Risk Reduction (GAR 2015) - Making Development Sustainable: the Future of Disaster Risk Management. Geneva, Switzerland, 2015.

UNISDR: Global Assessment Report on Disaster Risk Reduction: From Shared Risk to Shared Value: the Business Case for Disaster Risk Reduction, Geneva, Switzerland, 2013.

UNISDR: Global Assessment Report on Disaster Risk Reduction (GAR11), 2011. UNISDR: Indicators of Progress: Guidance on Measuring the Reduction of Disaster Risks and the Implementation of the Hyogo Framework for Action, 2008.

UNISDR: Living with risk: a global review of disaster reduction initiatives. United Nations International Strategy for Disaster Reduction Secretariat (UNISDR), 2004.

Warren, J. and Gilbert, R. O.: Statistical Methods for Environmental Pollution Monitoring, Technometrics, 30, 348, https://doi.org/10.2307/1270090, 1987. 
Welsch, H.: Environment and happiness: Valuation of air pollution using life satisfaction data, Ecol. Econ., 58, 801-813, https://doi.org/10.1016/j.ecolecon.2005.09.006, 2006.
Welsch, H. and Kühling, J.: Using happiness data for environmental valuation: issues and applications, J. Econ. Surv., 23, 385-406, https://doi.org/10.1111/j.1467-6419.2008.00566.x, 2009.

WMO: Standardized Precipitation Index - User Guide - WMONo. 1090, 2012. 